\title{
EFFECTS OF METHALLIBURE ON PITUITARY AND SERUM LEVELS OF IMMUNOREACTIVE LH IN SPAYED RATS
}

\author{
A. P. LABHSETWAR* AND A. L. WALPOLE \\ Pharmaceuticals Division, ICI Ltd, \\ Alderley Park, Cheshire
}

(Received 6th April 1972, accepted 25th April 1972)

Methallibure (ICI 33828) is a non-steroidal compound which has been found to inhibit secretion of gonadotrophins from the pituitary in a wide variety of species (Walpole, 1965). Decrease in pituitary gonadotrophin stores and/or secretion following treatment with methallibure has been found in the rat (Brown, 1963; W. R. Russell and A. L. Walpole, unpublished observations), pig (Garbers \& First, 1969; Stormshak, Leverage, Kelley, Gerrits \& Howland, 1970) and human (Loraine, Bell \& Foss, 1965). The compound is also known to cause restriction of food intake with a consequent loss in body weight. It is not known whether a decrease in the gonadotrophin synthesis and/or release following the methallibure treatment stems from the specific effects of the compound or is secondary to a restriction of food intake. In the present communication, pituitary and serum LH levels in the methallibure-treated rats and in controls which were either fully fed or pair fed have been compared, following radioimmunoassay.

Adult sexually mature rats of the Alderley Park strain I originally derived from the Wistar strain and bred randomly for several generations under specific pathogen-free conditions were exposed to standard light (from 06.00 to 20.00 hours) and temperature $\left(71\right.$ to $\left.72^{\circ} \mathrm{F}\right)$. Animals were bilaterally ovariectomized under ether anaesthesia during the dioestrous phase of the oestrous cycle and were allotted to three groups. One group served as a fully fed control and was allowed unrestricted access to food. Another group received methallibure $(100 \mathrm{mg} / \mathrm{kg} /$ day in $0.2 \mathrm{ml}$ of $0.5 \%$ Tween 80 ) orally for 16 days beginning on the day of ovariectomy. In this group, consumption of food was measured. The third group served as a pair-fed control which received the same amount of food consumed a day earlier by the methallibure-treated group. On the first day of the experiment, this group was fully fed.

Animals were killed with ether 1 day after the last administration of methallibure. Blood withdrawn from the posterior vena cava was centrifuged and serum samples were stored frozen until assayed. The anterior pituitaries were also removed and individually stored at $-20^{\circ} \mathrm{C}$ until assayed. The glands were homogenized in saline, centrifuged and the supernatant used for LH determina-

* Present address: Worcester Foundation for Experimental Biology, Shrewsbury, Massachusetts 01545, U.S.A. 


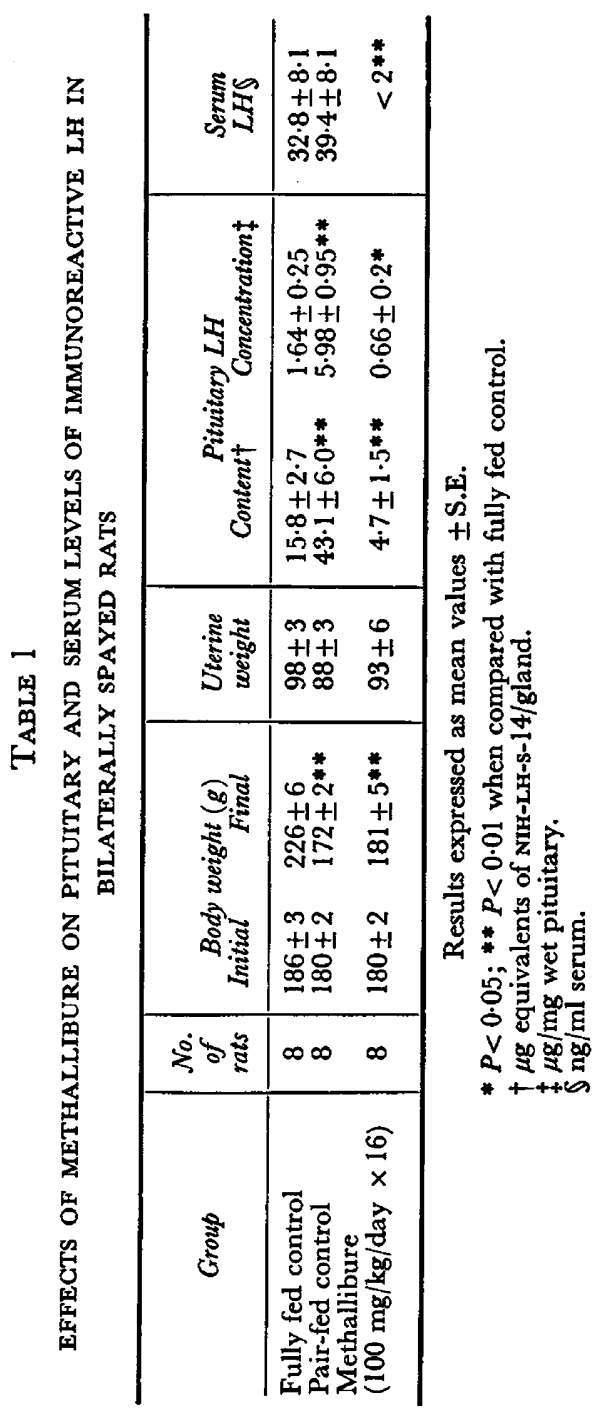


tion. Both pituitary extracts and serum samples were assayed for LH by radioimmunoassay (Niswender, Midgley, Monroe \& Reichert, 1968) using conditions already described (Labhsetwar, 1970). All LH values were expressed as ng or $\mu$ g equivalents of NIH-LH-S-14.

Results (Table 1) show that feeding of methallibure caused a significant loss in body weight during the experimental period. However, a similar loss in body weight occurred in the pair-fed controls $(P>0.05)$. This suggests that pair-feeding was successful in duplicating the effects of methallibure treatment on body weight. The restricted feeding caused an increased storage of $\mathrm{LH}$ in the pituitary as compared with that in the fully fed controls $(P<0.05)$ but serum levels of LH between these two control groups were comparable $(P>0.05)$. In the methallibure-treated rats, both pituitary and serum LH levels were markedly lower than those in either control group $(P<0.01)$. The serum LH level in the methallibure-treated group was in fact comparable to values found in the cyclic rats killed on the day of dioestrus $(2.2 \pm 0.52 \mathrm{ng} / \mathrm{ml}$, mean \pm S.E., $\mathrm{n}=4)$.

These results suggest that the treatment with methallibure decreases the synthesis and release of pituitary LH which is associated with a decline in the body weight. The effects on the body weight and LH appear to be independent as pair-feeding alone could not duplicate the effects of the drug.

We thank Miss Jill Mitchell and Mrs M. Redmond for technical assistance, The Endocrine Study Section, NIH, Bethesda, Md, for reference LH, Dr Niswender and Dr Midgley, University of Michigan for LH antiserum and Dr Reichert, Emory University, for purified LH for iodination.

\section{REFERENGES}

BRown, P. S. (1963) Observations on a dithiocarbamoylhydrazine as an inhibitor of pituitary gonadotrophic activity. F. Endocr. 26, 425.

Garbers, D. L. \& First, N. L. (1969) The effects of injected oestradiol-17 $\beta$, progesterone and dietary ICI 33828 on ovarian and pituitary functions in the sow and gilts. $\mathcal{7}$. Reprod. Fert. 20, 451.

LABHSETWAR, A. P. (1970) The serum level of immunoreactive $\mathbf{L H}$ in intact and spayed androgensterilized rats. F. Reprod. Fert. 23, 349.

LoRAine, J. A., BeLL, E. T. \& Foss, G. L. (1965) Effect of a derivative of dithiocarbamoylhydrazine on hormone excretion in a patient with precocious puberty. Br. med. J. i, 98.

Niswender, G. D., Midgley, A. R., Jr, Monroe, S. E. \& Reichert, L. E., JR (1968) Radioimmuno-

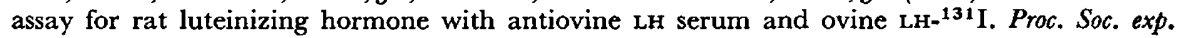
Biol. Med. 128, 807.

Stormshak, F., Leverage, W. E., Jr, Kelley, H. E., Gerrits, R. J. \& Howland, B. E. (1970) Hypothalamo-hypophysial and ovarian characteristics of gilts fed methallibure. $\mathcal{F}$. Anim. Sci. 30, 556.

WaLPOLE, A. L. (1965) Nonsteroidal agents inhibiting pituitary gonadotrophic function. In: Agents Affecting Fertility, p. 159. Eds. C. R. Austin and J. S. Perry. Churchill, London. 